Bull. Fac .Agric., Cairo Univ. 68: 133-145 (2017).

\title{
PERFORMANCE OF TWO SUGARCANE VARIETIES AS AFFECTED BY IRRIGATION INTERVAL AND SEED RATE
}

(Received:6.6.2017)

\author{
By \\ M. A. Bekheet, R. M. Abd El-Aziz and M. M. El-Zeny \\ Agronomy Department, Sugar Crops Research Institute, Agricultural Research Center, Giza, Egypt
}

\begin{abstract}
The present study was conducted at Shandaweel Agricultural Research Station $\left(26.5013^{\circ}\right.$ N, 31.7651 ${ }^{\circ}$ E), Sohag Governorate , Egypt in 2015/2016 and 2016/2017 seasons to deternine optimize irrigation interval and seed rate of sugarcane production. The current study included eighteen treatments representing the combinations among two sugarcane varieties (GizaTaiwan 54-9 and G. 2003-47), three irrigation intervals (10, 15 and 20 days) and three seed rates of (25200, 37800 and 50400 buds/fed) resulted from one, one and half and two rows of seed setts . /furrow which contain three buds for each, respectively. The treatments were allocated in a Randomized Complete Block Design using a split-split plot arrangement with three replications. The results showed that decreasing irrigation intervals from 20 to 15 days significantly increased stalk length, stalk diameter, number of millable canes/fed, cane and sugar yields/fed in both seasons. However, brix, sucrose and sugar recovery percentages were negatively and significantly affected by increasing the period between irrigations. Varieties differed significantly in their response to all the studied characters. The commercial variety G.T.54-9 recorded higher values of stalk length, stalk diameter and cane yield/fed, while the promising variety G. 2003-47 had higher number of millable canes/fed, brix, sucrose and sugar recovery percentages as well as sugar yield, in both seasons. Planting sugarcane using two rows of seed setts/furrow attained significant increases in stalk length and the number of millable canes/fed, in both seasons, while thickest stalks were obtained by 1.0 drill of cane cuttings. The higher brix, sucrose and sugar recovery percentages, cane and sugar yields were obtained by 1.5 drills of cane cuttings in both seasons. Under conditions of the present investigation, planting any of the evaluated cane varieties using 1.5 and/or 2.0 drills of cane setts and irrigating them at 10 and/or 15-day intervals can be recommended to get the maximum cane yield/fed. However, planting sugarcane variety G. 2003-47 using 1.5 drills of cane cuttings and irrigating it every 15 days can be recommended to obtain the highest sugar yield/fed.
\end{abstract}

Key words: sugarcane, varieties, irrigation intervals, seed rate.

\section{INTRODUCTION}

Irrigation is one of the major factors affecting germination, tillering, boom stage, sugar accumulation and hence cane and sugar yields. In this respect, sugar cane is adversely affected by waterlogging, which creates several problems including leaching of water by percolation and available nutrients beyond root zone, lodging, pests and diseases and harvesting difficulties. In addition, excessive application of water causes inadequate soil aeration and low water potential. Gomaa (2000) irrigated sugarcane every 14, 21, 28, 35 and 42 days. His results showed that sugar recovery percentage decreased as irrigation intervals decreased. Increasing irrigation intervals reduced cane yield. Bekheet (2006) showed that decreasing irrigation intervals from 20 to 12 days significantly increased stalk length, diameter and cane yield. Applying irrigation every 12 and/or 16 days attained significant increases in the number of millable canes/fed and sugar yield/fed. However, sucrose and sugar recovery percentages were negatively and significantly affected by increasing irrigation intervals. Hossain et al. (2009) reported that irrigation of sugarcane at 
21-day intervals resulted in higher establishment, tiller, millable cane and yield of cane compared to irrigation at 28,35 or 42 day intervals. Ahmed et al. (2014) showed that increasing the number of irrigations from 14 to 18 and 22 considerably increased stalk length, number of millable canes $/ \mathrm{m}^{2}$, reducing sugars, cane and sugar yields/fed. Meanwhile, sucrose, purity and sugar recovery percentages were insignificantly influenced by irrigation numbers.

As for the variance between cane varieties, significant differences among sugarcane genotypes were reported by Ahmed et al. (2011), El-Geddawy et al. (2012), Ahmed et al. (2014), Abd El-Aal et al. (2015), and El-Geddawy et al. (2015).

Plant density (number of drills of cane cuttings/furrow) could be the main environmental factors affecting sugarcane productivity and quality. El-Sogheir (1999) noticed that seed rate (1.0, 1.5 and 2.0 drill/furrow) significantly increased stalk length, stalk diameter, cane and sugar yields, while sucrose $\%$ was insignificantly affected. Planting sugarcane at two rows of cane cutting increased stalk length, cane and sugar yields. Avtar (2000) planted sugarcane at 50000 or $70000 /$ ha threebudded setts and found that cane yield was significantly higher with dense planting. Shahid, et al. (2002) found that sugarcane established at 62500 and 75000 double-budded setts/ha produced the highest cane (73.41 and $72.63 \mathrm{t} / \mathrm{ha}$ ) and sugar (10.17 and 10.1 t/ha) yields. Ahmed (2003) planted sugarcane using 25200, 37800 and 50400 buds/fed (1.0, 1.5 and 2.0 drills of cane setts). He found that increasing seed rate increased number of millable canes $/ \mathrm{m}^{2}$ and cane and sugar yields. However, stalk length, stalk diameter and sugar recovery percentages were insignificantly affected by seed rate. Ismail et al. (2008) showed that planting sugarcane at two rows of seed setts/furrow attained significant increases in stalk length, the number of millable cane/fed, cane yield/fed and sugar yield/fed in both plant cane and $1^{\text {st }}$ ratoon crops, while the thickest stalks were obtained by drilling one and half seed setts pattern. They added that quality traits were insignificantly affected by seed rate. El-Geddawy et al. (2015) found that dual drilling of cane seed sets increased the number of millable canes, cane and sugar yields.

The objective of this study was to find out the best seed rate and irrigation intervals to attain the maximum cane and sugar yields of both sugarcane varieties under the conditions of Sohag
Governorate.

\section{MATERIALS AND METHODS}

The present study was conducted at Shandaweel Agricultural Research Station, $\left(26.5013^{\circ} \mathrm{N}, 31.7651^{\circ} \mathrm{E}\right)$, Sohag Governorate in $2015 / 2016$ and $2016 / 2017$ to find out the optimal irrigation interval and seed rate to get the highest cane and sugar yields from two sugarcane varieties. This work included eighteen treatments representing the combinations among two sugarcane varieties (G.T. 54-9 and G. 200347), three irrigation intervals $(10,15$ and 20 days) and three seed rates $(25200,37800$ and 50400 buds/fed), allocated in a Randomized Complete Block Design using a split-split plot arrangement with three replications. The three seed rates were obtained by planting 8400 , 12600 and 16800 of three-budded cane cuttings/fed, arranged in furrows as 1.0, 1.5 and 2.0 rows/furrow, respectively. Irrigation treatments were allocated in the main plots, separated with ditches of $1.5 \mathrm{~m}$ width to prevent side seepage of water among them. The sub plots were assigned for the two sugarcane verities, while the three seeding rates/fed were distributed in the sub-sub plots. Sugarcane varieties were planted in the $1^{\text {st }}$ week of March and harvested at the age of 12 months in plant cane. Unit area was $42 \mathrm{~m}^{2}$ with 7 ridges of 6 meters in length and $1.0 \mathrm{~m}$ apart.

Mechanical and chemical analyses of the experimental soil showed that the upper $30 \mathrm{~cm}$ of the soil was clay loam (29.4\% sand, $10.4 \%$ silt and 59.6\% clay) which contained 34.0, 11.7 and $210 \mathrm{ppm}$ available $\mathrm{N}, \mathrm{P}, \mathrm{K}$, respectively, with a $\mathrm{pH}$ of 7.4. Overall doses of NPK fertilizers were given as recommended by Sugar Crops Research Institute. Nitrogen fertilizer (Urea, $46.5 \% \mathrm{~N}$ at the rate of $200 \mathrm{~kg} / \mathrm{fed}$ ) was added in two equal doses, at 50 days from planting, (preceded with hoeing) and one month later. Phosphorus fertilizer was added during seed bed preparation at the rates of $30 \mathrm{~kg} \mathrm{P}_{2} \mathrm{O}_{5}$ (as super phosphate, 15.5\%). $48 \mathrm{~kg} \mathrm{~K}_{2} \mathrm{O}$ (as potassium sulphate $48 \% \quad \mathrm{~K}_{2} \mathrm{O}$ )/fed with the second addition of nitrogen fertilizer. The following data were recorded:

At harvest, a sample of 20 millable cane stalks was collected immediately after harvesting, cleaned to determine the following traits:

* Stalk length and diameter $(\mathrm{cm})$.

The same samples were thereafter crushed to determine the following quality characteristics: * Brix percentage (total soluble solids, TSS \%) 
in juice was determined using Brix Hydrometer standardized at $20 \mathrm{C}^{\circ}$.

* Sucrose $/ 100 \mathrm{~cm}^{3}$ juice was determined using Sacharemeter according to A.O.A.C. (1995).

* Sugar recovery percentage was calculated as follows:

Sugar recovery $\%=$ richness $\%$ x purity $\%$,

Where: richness $=($ sucrose $\% \times$ factor $) / 100$.

Factor $=100-[$ fiber $\%+$ physical impurities $\%+$ percent water free from sugar].

Plants of the guarded rows were harvested, topped and the following parameters were recorded:

* Number of millable canes/fed was calculated on plot basis.

* Cane yield (ton/fed) was calculated on plot basis.

* Sugar yield (ton/fed), which was estimated according to the following equation:

Raw sugar production $=$ cane yield (tons/fed) $\mathrm{x}$ sugar recovery $\%$.

\subsection{Water relations}

\subsubsection{Water consumptive use $(C U)$.}

It was estimated using the soil sampling method and calculated according to the technique and the following equation of Israelsen and Hansen (1962):

$\mathrm{CU}=\mathrm{D} \times \mathrm{D}_{\mathrm{b}} \times(\mathrm{Q} 2-\mathrm{Q} 1) / 100$

Where:

$\mathrm{CU}=$ water consumptive use $(\mathrm{cm})$ in the effective root zone $(60 \mathrm{~cm})$.

$\mathrm{D}=$ soil layer depth.

$\mathrm{D}_{\mathrm{b}}=$ soil bulk density $\left(\mathrm{g} / \mathrm{cm}^{3}\right)$.

$\mathrm{Q}_{1}=$ soil moisture $\%$, before irrigation.

$\mathrm{Q}_{2}=$ soil moisture \%, 48 hours after irrigation.

\subsubsection{Water use efficiency (WUE)}

It was calculated on cane and sugar basis as shown by Vites (1965) as follows:

1. WUE ( $\mathrm{kg}$ cane $/ \mathrm{m}^{3}$ water) = cane yield $(\mathrm{kg} / \mathrm{fed}) /$ water consumptive use $\left(\mathrm{m}^{3} / \mathrm{fed}\right)$.

2. WUE ( $\mathrm{kg}$ sugar $/ \mathrm{m}^{3}$ water $)=$ sugar yield $(\mathrm{kg} / \mathrm{fed}) /$ water consumptive use $\left(\mathrm{m}^{3} / \mathrm{fed}\right)$.

The collected data were statistically analyzed according to Snedecor and Cochran (1981). Treatment means were compared using LSD at 5\% level of probability.

\section{RESULTS AND DISCUSSION \\ 3.1. Stalk length and diameter}

Data in Table (1) showed that increasing irrigation frequency, i.e. shortening irrigation intervals up to 10 and 15 days led to a significant increase in stalk length amounted to 6.9 and 14.2 $\mathrm{cm}$ in the $1^{\text {st }}$ season, corresponding to 7.9 and
$14.2 \mathrm{~cm}$ in the $2^{\text {nd }}$ one, respectively, as compared with that recorded when irrigation was given at 20 days intervals. Likewise, an increase of 0.02 and $0.05 \mathrm{~cm}$ in stalk diameter was recorded in the $1^{\text {st }}$ season, corresponding to 0.06 and 0.04 $\mathrm{cm}$ in the $2^{\text {nd }}$ one. These findings may be due to that short irrigation interval ensures a continuous and adequate water supply for plants, which enhances cell division and elongation leading to an increase in stalk length and diameter. These results are in accordance with those reported by Gomaa (2000) and Bekheet (2006).

The results revealed that the two sugarcane varieties differed significantly in stalk length in the $1^{\text {st }}$ season and stalk diameter in both seasons. The commercial variety G.T. 54-9 had thicker stalks compared with that of the promising variety G. 2003-47. These results are in agreement with those of Ahmed et al. (2011) and Abd El-Aal et al. (2015).

Data in Table (1) clarified that stalk length was significantly affected by planting density in both seasons. The results showed that planting sugarcane using two rows of cane cuttings significantly attained higher stalks. This result could be due to the great competition for solar radiation among plants grown under the higher density which led to increasing their height. This result coincided with that reported by Shahid $e t$ al. (2002) and El-Geddawy et al. (2015).

Data in Table (1) showed that stalk diameter was significantly and gradually decreased as planting population was increased from 1.0 to 1.5 and 2.0 drills of cane setts. This decrease may be probably due to the competition among plants for growth factors, i.e. water, nutrients and solar radiation.

The results cleared that stalk length and diameter were significantly affected by the interaction of irrigation interval $x$ cane variety in the $1^{\text {st }}$ season only.

The interaction between irrigation intervals and seed rates had significant effects on stalk length and diameter in both seasons. The highest stalk length was obtained by irrigating sugarcane every 15-days planted with two rows of cuttings, while the thickest stalks were obtained by planting sugarcane using one row of cane setts and the application of irrigation water at 15-day intervals.

Cane varieties $\mathrm{x}$ seed rate interaction had a significant effect on stalk length in both season, while it was significant for stalk diameter only in the $1^{\text {st }}$ season.

The second order interaction among the three 
Table (1): Effect of irrigation intervals, cane varieties, seed rate and their interactions on stalk length and diameter (cm) in $2015 / 2016$ and 2016/2017 seasons

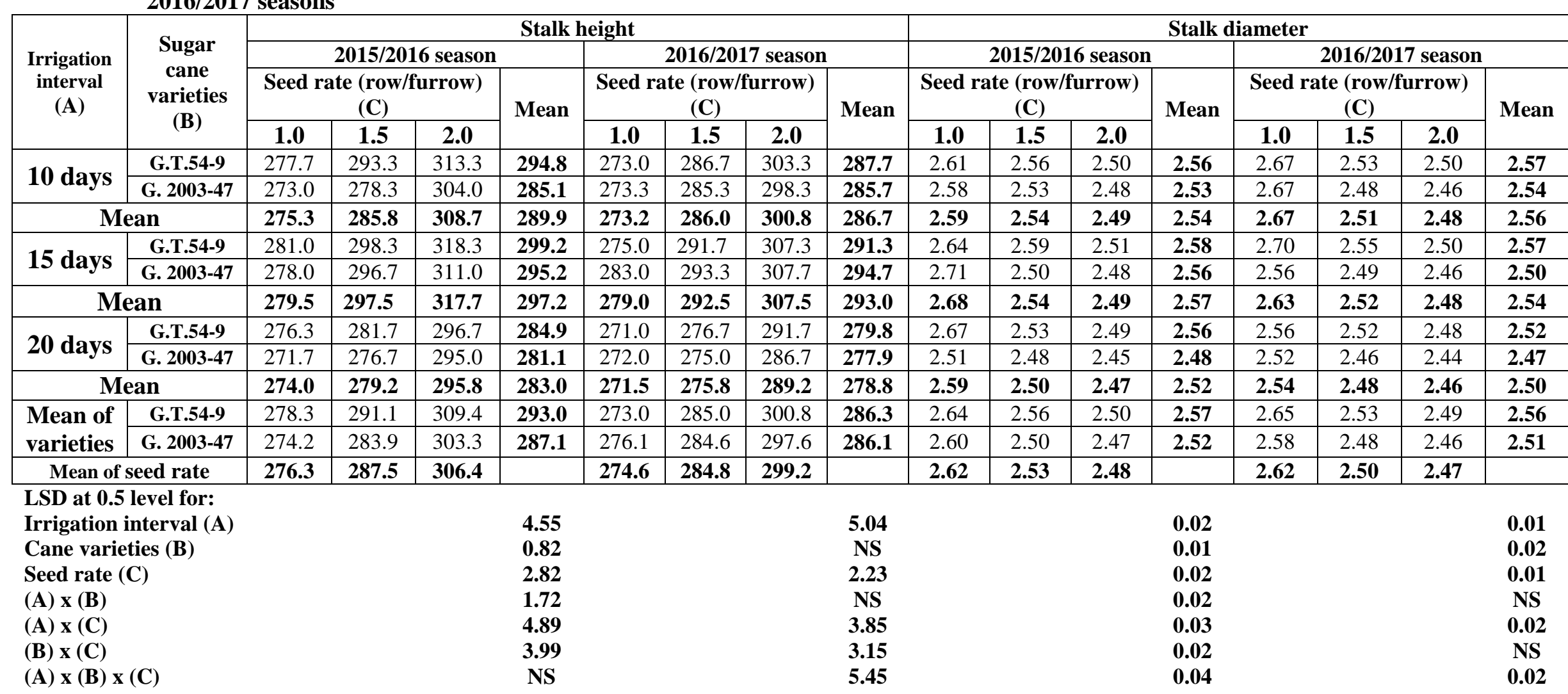


studied factors had a significant effect on stalk length in the $2^{\text {nd }}$ season only and stalk diameter in both seasons. Planting sugarcane G. 2003-47 using two rows of cane cuttings and supplying plants with irrigation water every 15-day resulted in the highest stalks in the second season. The highest values of stalk diameter were recorded by G. 2003-47 (in the $1^{\text {st }}$ season) and G.T. 54-9 (in the $2^{\text {nd }}$ one), in sugarcane planted with one row of cuttings and irrigated at 15-day intervals.

3.2. Number of millable cane and canes yield/fed

The results in Table (2) showed that the number of millable cane and cane yield/fed were significantly influenced by irrigation intervals in both seasons. Irrigation of sugarcane plants every 15 days resulted in significant increases amounted to 0.740 and 3.670 thousand millable canes/fed, in the $1^{\text {st }}$ season, corresponding to 0.980 and 3.540 calculated on plot basis millable canes/fed, in the $2^{\text {nd }}$ one, respectively compared with that irrigated every 10 or 20 days. Similarly, cane yield/fed increased by 1.810 and 5.580 tons, in the $1^{\text {st }}$ season corresponding to 0.310 and 5.140 tons in the $2^{\text {nd }}$ one, respectively. The increase in cane yield can be referred to the increase in both stalk length and the number of millable canes. These results are in line with those found by Gomaa (2000) and Bekheet (2006).

Results in Table (2) pointed out that the examined sugarcane varieties varied significantly in the number of millable canes/fed, in both seasons. Sugar cane G. 2003-47 variety over passed the commercial variety G.T. 54-9 by 0.380 and 0.210 thousand of millable canes/fed, in the $1^{\text {st }}$ and $2^{\text {nd }}$ season, respectively. The difference between varieties in this trait could be mainly due to the capability of the variety in teller production, which in turn was reflected on the final number of millable canes/fed. The variation between cane varieties in the number of millable canes was also reported by Ahmed $e t$ al. (2011), El-Geddawy et al. (2012), Ahmed et al. (2014) and El-Geddawy et al. (2015).

Results in Table (2) revealed that the evaluated sugarcane varieties differed significantly in cane yield/fed in the $2^{\text {nd }}$ season only. The commercial variety G.T54-9 produced 1.58 tons of canes/fed higher than that given by G.2003-47. This result was in agreement with those obtained by Ahmed et al. (2011) and Abd El-Aal et al. (2015).

The results proved that dual drilling of cane cuttings significantly raised the number of millable cane by 8.02 and 5.22 as well as 6.88 and 4.28 thousand stalks/fed in the $1^{\text {st }}$ and $2^{\text {nd }}$ season, respectively compared with 1.0 and 1.5 drills of cane cuttings. The influence of seed rate on the number of millable canes was reported by Shahid et al.(2002) and El-Geddawy et al. (2015).

Results in Table (2) show that seed rate had a positive and significant effects on cane yield/fed. It was found that planting sugarcane using 1.5 rows of cane setts produced higher cane yield amounted to 8.08 and 0.67 in the $1^{\text {st }}$ season, as well as 8.70 and 0.65 ton/fed in the $2^{\text {nd }}$ one, respectively compared to 1.0 or 2.0 drills of cane cuttings. The increase in cane yield resulted from planting 1.5 rows of cutting seeds can be attributed to its positive effect on the number of millable canes, which in turn was reflected on cane yield. These results are in line with those mentioned by Shahid et al. (2002) and Ahmed (2003).

Regarding the effect of irrigation intervals $\mathrm{x}$ cane varieties, the results showed significant differences in the number of millable canes of the two varieties under three irrigation intervals in both seasons, while, cane yield/fed was affected by the interaction in the first season only. It was found that the variance between G.T.54-9 and G.2003-47 varieties was insignificant, irrigated at longer intervals (every 15 and 20 days). However, irrigated at shorter interval (every 10 days) G.T.54-9 showed the significant superiority in cane yield over G.2003-47 variety.

The interaction between irrigation intervals and seed rate was significant for millable canes and canes yield/fed in both seasons. The highest number of millable canes was obtained by planting sugarcane using two rows of cane seeds and irrigating it every 15 days, in both seasons, while the highest cane yield/fed was obtained by applying irrigation at 15-day intervals for sugarcane planted using 1.5 rows of cane cuttings, in the $1^{\text {st }}$ season and two rows, in the $2^{\text {nd }}$ one.

Cane variety $\mathrm{x}$ seed rate interaction had a significant effect on the number of millable canes/fed in both season. The highest number of millable canes/fed was obtained by planting G.2003-47 variety with two drills of cane cuttings. Also, cane yield/fed was significantly influenced by the interaction between cane varieties and seed rates, in the $1^{\text {st }}$ season only, where the highest cane yield was attained by planting G. 2003-47 with 1.5 rows of cane setts.

The $2^{\text {nd }}$ order interaction among the three 
Table (2): Effect of irrigation intervals, cane varieties, seed rate and their interactions on the number of millable canes (thousand/fed) and cane yield (ton/fed) in 2015/2016 and 2016/2017 seasons

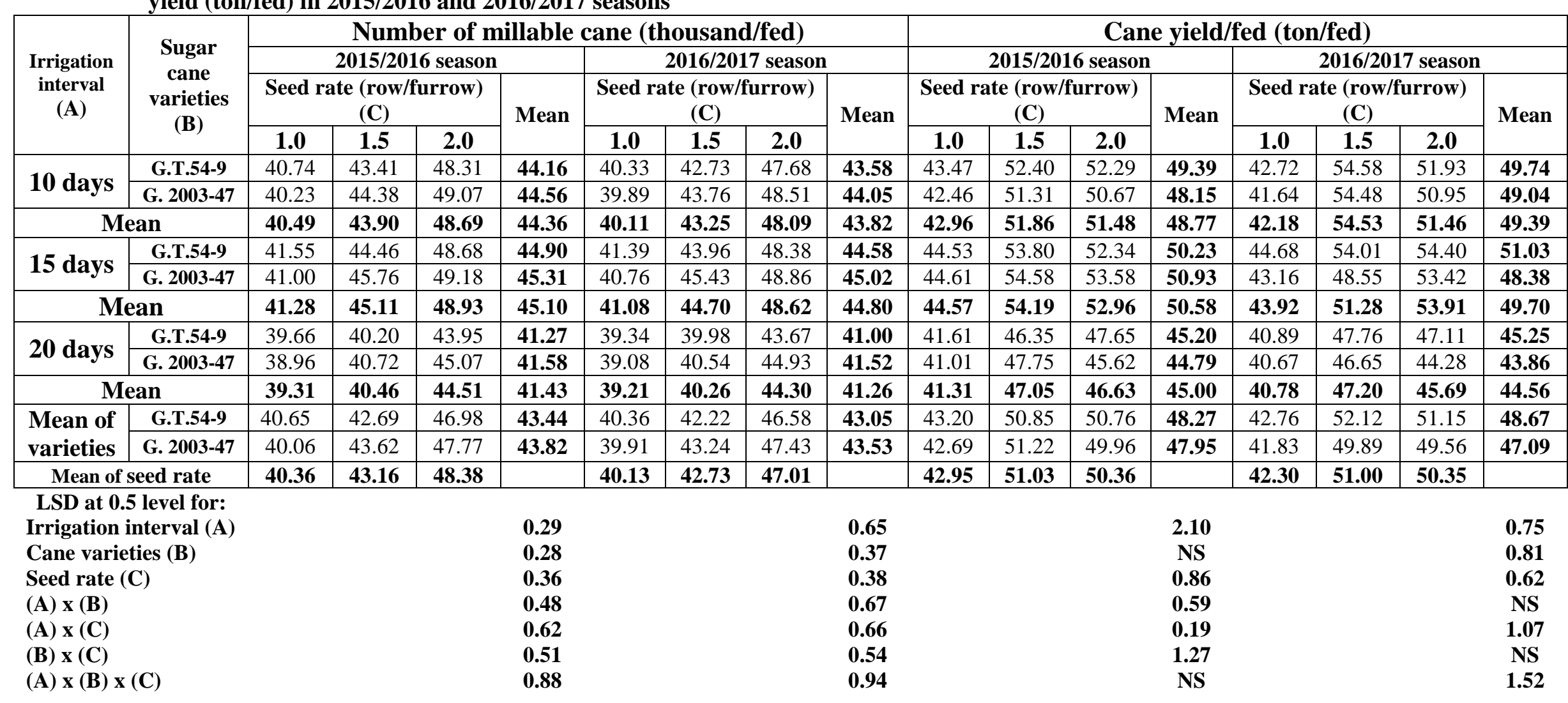


studied factors had a significant influence on the number of millable canes/fed in both seasons, where the maximum value of this trait was recorded by G.2003-47 planted with two drills of cane cuttings, without significant variance between G.T.54-9 planted with the same seed rate, when the two varieties were irrigated every 10 and/or 15 days.

Cane yield/fed was significantly affected by the interaction among the three studied factors in the $2^{\text {nd }}$ season only, where the maximum cane yield was given by G.T.54-9 grown using 1.5 and/or 2.0 drills of cane setts, when sugarcane was irrigated at 10 and/or 15-day intervals, respectively, without significant difference with that produced by G.2003-47.

\subsection{Juice quality percentages and sugar yield 3.3.1.Brix and sucrose percentage}

Data in Table (3) revealed that irrigation of sugarcane plants every 20 days caused a significant increase in brix and sucrose percentages, while applying water every 10 days recorded the lowest values of these traits in both seasons. This result may be due to that increasing irrigation frequency, i.e. at shorter intervals increased water content in stalks and hence decreased sucrose, determined as a percentage in cane juice. The same results were obtained by Gomaa (2000) and Bekheet (2006).

The results in Table (3) cleared that the two sugarcane varieties differed significantly in brix and sucrose percentages. The promising sugarcane variety G. 2003-47 recorded higher values of brix and sucrose \% compared with those of G.T54-9 in both seasons. These results may indicate that sucrose percentage is mainly affected by genetic make-up. Similar results were found by Ahmed et al. (2011) and Abd ElAal et al. (2015).

The results cleared significant response of brix and sucrose percentages to seed rates. Drilling 1.5 rows of cane cuttings resulted in higher values of brix and sucrose \%, compared with those given by $1.0 \mathrm{and} /$ or 2.0 drills, in the two growing seasons. These results are in agreement with those obtained by Shahid et al. (2002) and El-Geddawy et al. (2015).

The interaction between irrigation intervals and sugarcane varieties significantly affected brix $\%$ in both seasons. The highest brix $\%$ was obtained by planting G. 2003-47 variety and applying irrigation at 20-day intervals.

The interaction between irrigation intervals and seed rates had a significant effect on brix $\%$ in the $1^{s t}$ season only, where the highest brix \% was obtained by planting sugarcane using 1.5 rows of cane cuttings and irrigating it at 20-day intervals.

Cane varieties $\mathrm{x}$ seed rates interaction had a significant effect on brix $\%$ in the $2^{\text {nd }}$ season only. Meanwhile, it had significant effect on sucrose percentage in both seasons.

The $2^{\text {nd }}$ order interaction among the three studied factors had a significant effect on brix and sucrose percentages in both seasons. Planting sugarcane G. 2003-47 with 1.5 rows of cuttings and applying irrigation at 20-day intervals recorded the highest brix and sucrose in the $1^{\text {st }}$ season. Planting the same variety with the same planting density and irrigated every 15 days resulted in the highest values of the two traits, in the $2^{\text {nd }}$ season.

\subsubsection{Sugar recovery percentage and sugar yield}

The results in Table (4) showed that sugar recovery $\%$ was significantly affected by the studied irrigation intervals in the $2^{\text {nd }}$ season only, where it was noticed that shortening irrigation intervals from 20 to 15 and 10 days caused a relative and gradual decrease in sugar recovery $\%$.

The used irrigation intervals affected sugar yield/fed significantly, in both seasons. Supplying sugarcane with water every 15 days attained 0.370 and 0.720 ton of sugar/fed higher than that irrigated at 10 and 20 day-intervals, in the $1^{\text {st }}$ season, corresponding to 0.070 and 0.500 ton/fed, in the $2^{\text {nd }}$ one. In addition, differences in sugar yield produced from sugarcane irrigated every 10 and/or 15 days was insignificant, in the $2^{\text {nd }}$ season. These results are in accordance with those reported by Gomaa (2000) and Bekheet (2006).

Data in Table (4) revealed that the evaluated sugarcane varieties differed significantly in sugar recovery $\%$ and sugar yield/fed, in both seasons. Sugarcane variety G. 2003-47 recorded 0.92 and $1.60 \%$ higher in sugar recovery than that of G.T. 54-9, in the $1^{\text {st }}$ and $2^{\text {nd }}$ season, successively. Likewise, an increment of 0.40 and 0.57 ton of sugar/fed was produced by the promising variety G. 2003-47 higher than that gained from the commercial G.T. 54-9 variety, in the $1^{\text {st }}$ and $2^{\text {nd }}$ season, respectively. These results coincided with those found by Ahmed et al. (2011) and Abd El-Aal et al. (2015).

Sugar recovery $\%$ and sugar yield were significantly influenced by seed rates in both seasons. Growing sugarcane using 1.5 drills of cane cuttings raised sugar recovery percentage 
Table (3): Effect of irrigation intervals, cane varieties, seed rate and their interactions on brix and sucrose percentages in $2015 / 2016$ and $2016 / 2017$ seasons

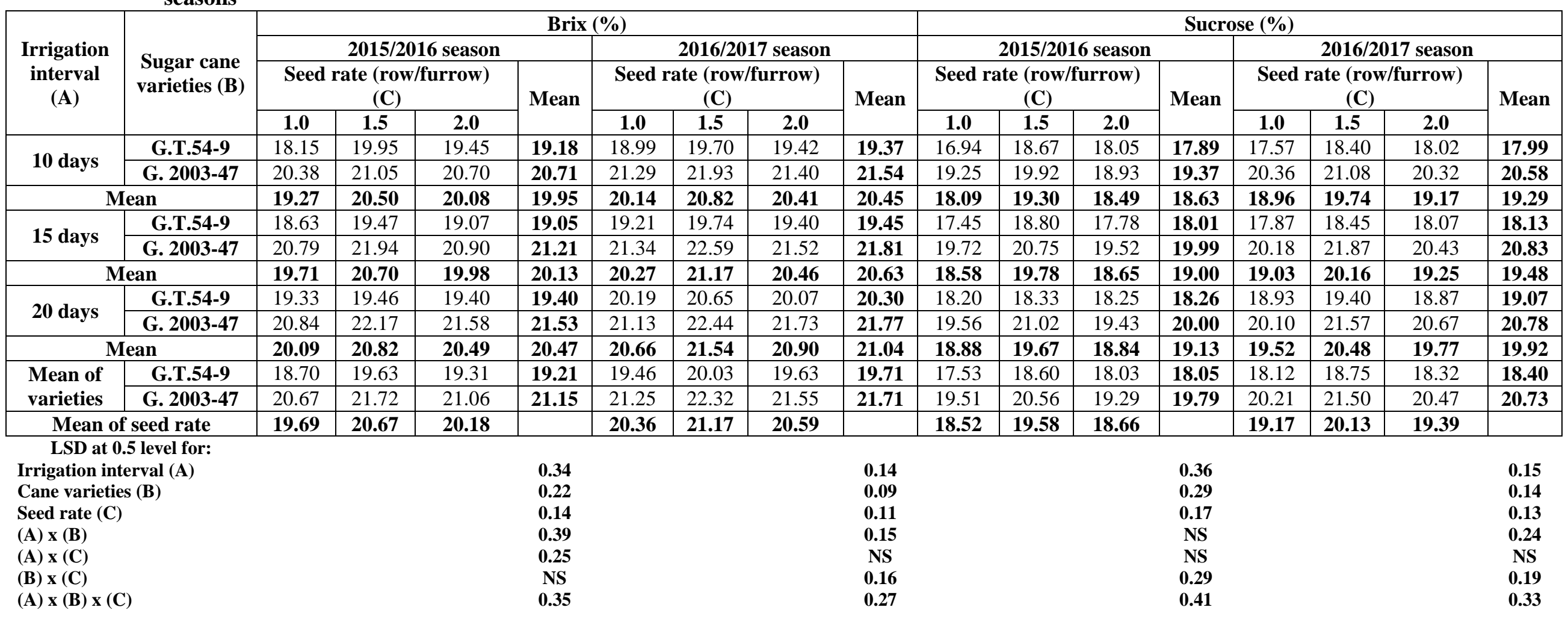


Table (4): Effect of irrigation intervals, cane varieties, seed rate and their interactions on sugar recovery percentage and sugar yield (ton/fed) in $2015 / 2016$ and $2016 / 2017$ seasons

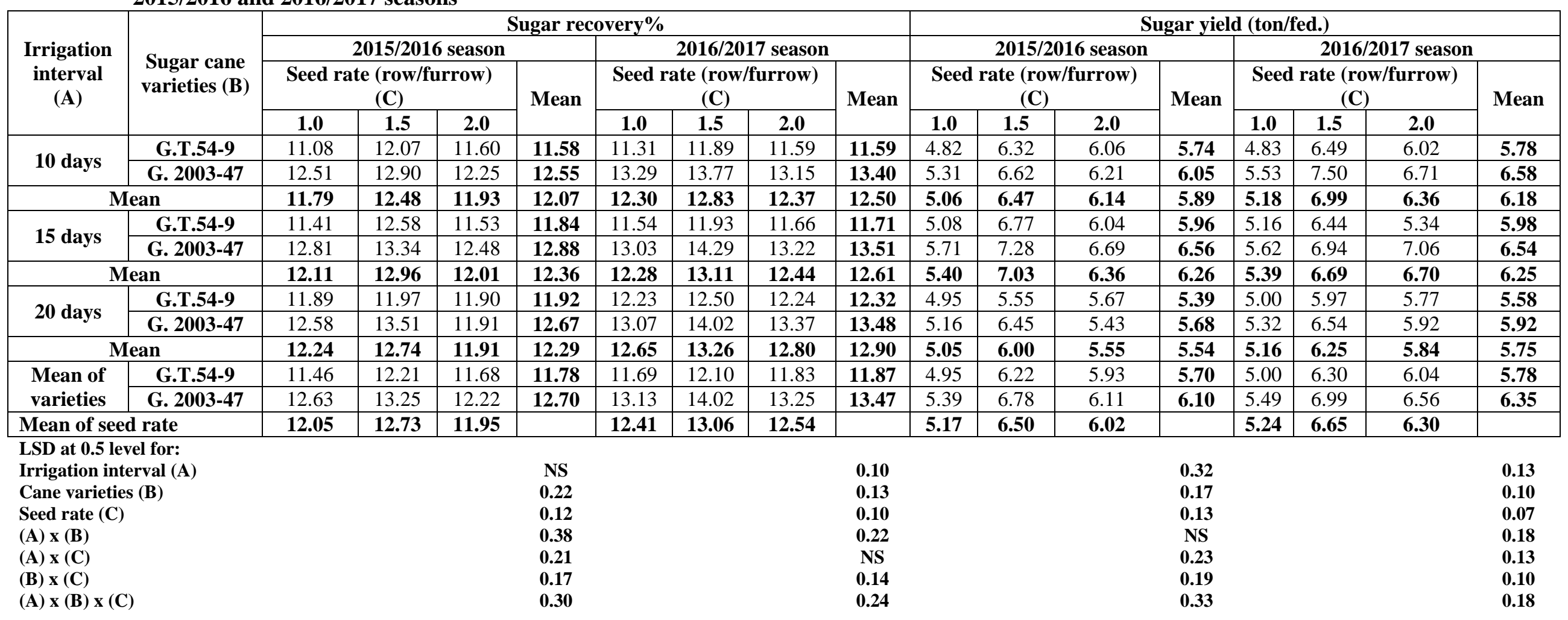




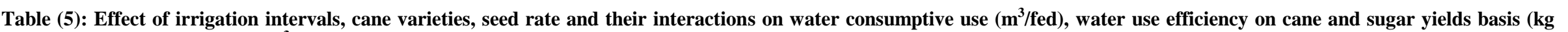
canes and/or sugar/ $\mathrm{m}^{3}$ water consumed) in 2015/2016 and 2016/2017 seasons

\begin{tabular}{|c|c|c|c|c|c|c|c|c|c|c|c|c|c|c|c|c|c|c|c|c|c|c|c|c|c|}
\hline \multirow{4}{*}{$\begin{array}{l}\text { Irrigation } \\
\text { interval }(A)\end{array}$} & \multirow{4}{*}{$\begin{array}{c}\text { Sugar } \\
\text { cane } \\
\text { varieties } \\
\text { (B) }\end{array}$} & \multicolumn{8}{|c|}{ Water consumptive use $\left(\mathrm{m}^{3} /\right.$ fed $)$} & \multicolumn{8}{|c|}{$\begin{array}{c}\text { Water use efficiency of cane yield basis ( } \mathrm{kg} \\
\text { cane stalk } / \mathrm{m}^{3} \text { water consumed) }\end{array}$} & \multicolumn{8}{|c|}{$\begin{array}{c}\text { Water use efficiency of sugar yield basis (kg } \\
\text { sugar } / \mathrm{m}^{3} \text { water consumed) }\end{array}$} \\
\hline & & \multicolumn{4}{|c|}{ 2015/2016 season } & \multicolumn{4}{|c|}{ 2016/2017 season } & \multicolumn{4}{|c|}{ 2015/2016 season } & \multicolumn{4}{|c|}{ 2016/2017 season } & \multicolumn{4}{|c|}{ 2015/2016 season } & \multicolumn{4}{|c|}{$2016 / 2017$ season } \\
\hline & & \multicolumn{3}{|c|}{$\begin{array}{c}\text { Seed rate } \\
\text { (row/furrow) } \\
(\mathrm{C}) \\
\end{array}$} & \multirow[t]{2}{*}{ 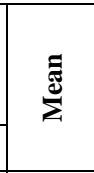 } & \multicolumn{3}{|c|}{$\begin{array}{c}\text { Seed rate } \\
\text { (row/furrow) } \\
(\mathrm{C}) \\
\end{array}$} & \multirow[t]{2}{*}{ 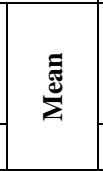 } & \multicolumn{3}{|c|}{$\begin{array}{c}\text { Seed rate } \\
\text { (row/furrow) } \\
(\mathrm{C}) \\
\end{array}$} & \multirow[t]{2}{*}{$\sum_{\Sigma}^{\bar{E}}$} & \multicolumn{3}{|c|}{$\begin{array}{c}\text { Seed rate } \\
\text { (row/furrow) } \\
(\mathrm{C}) \\
\end{array}$} & \multirow[t]{2}{*}{ 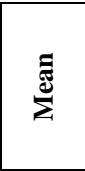 } & \multicolumn{3}{|c|}{$\begin{array}{c}\begin{array}{c}\text { Seed rate } \\
\text { (row/furrow) } \\
(\mathrm{C})\end{array} \\
\end{array}$} & \multirow[t]{2}{*}{$\sum_{\Sigma}^{\bar{E}}$} & \multicolumn{3}{|c|}{$\begin{array}{c}\text { Seed rate } \\
\text { (row/furrow) } \\
(\mathrm{C})\end{array}$} & \multirow[t]{2}{*}{ 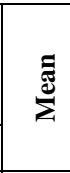 } \\
\hline & & 1.0 & 1.5 & 2.0 & & 1.0 & 1.5 & 2.0 & & 1.0 & 1.5 & 2.0 & & 1.0 & & 2.0 & & & 1.5 & 2.0 & & $\mathbf{1 . 0}$ & 1.5 & 2.0 & \\
\hline \multirow{2}{*}{10 days } & 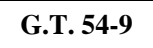 & 250.4 & 8450.6 & 8780.5 & 93.8 & 8450.4 & 8750.6 & 8980.5 & 8727.2 & 5.27 & 6.20 & 5.9 & 5.81 & 5 & & & .70 & & & .69 & 8 & 0.57 & 4 & 0.67 & 0.66 \\
\hline & G. 2 & 350.6 & 8580.7 & 8850.3 & 8593.9 & 8550.6 & 8980.7 & 9000.3 & 8843.9 & 5.08 & 5.98 & 5.73 & 5.60 & 4.87 & 6.07 & 5.6 & 555 & 064 & 0.77 & 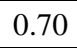 & 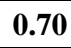 & 065 & 0.84 & 0.75 & 0.74 \\
\hline \multicolumn{2}{|c|}{ Iean } & 8300.5 & 8515.6 & 8815.4 & 8543.5 & 8624.9 & 8661.4 & 8610.1 & 8632.2 & s & 9 & & & & & & a.r. & & & & & & & & (2) \\
\hline \multirow{2}{*}{15 days } & G.T. 54-9 & 025.5 & 8125.7 & 8345.4 & 8165.5 & 8125.2 & 8325.3 & 8545.4 & 8331.9 & 5.55 & 6.62 & 6.27 & 0 & $\mathrm{~J}$ & 6.49 & 6.3 & 6.12 & 0.05 & & 0.72 & 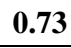 & 0.04 & & 0.62 & 0.72 \\
\hline & G. 200 & 080.3 & 8250.6 & 8535.9 & 8288.9 & 8180.3 & 8450.3 & 8745.2 & 8458.6 & 5.52 & 6.62 & 6.2 & 6.14 & 5.28 & 5. & & 5.72 & & 0. & 0.78 & 0.79 & 0.69 & 0.82 & 0.81 & 0.77 \\
\hline \multicolumn{2}{|c|}{ Mean } & 8052.9 & 8188.2 & 8440.6 & 8227.2 & 8152.7 & 8387.8 & 8645.3 & 8395.3 & 5.53 & 6.62 & 6. & 6. & 5. & 6 & 6.2 & 5.92 & 06 & 0 & 5 & 6 & 0.66 & 0.80 & I & 0.74 \\
\hline \multirow{2}{*}{20 days } & 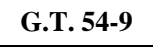 & 35.2 & 35.7 & 7855.8 & 7725.6 & 7835.3 & 7905.6 & 7966.3 & 7902.4 & 5.45 & 6. & 6.07 & 5. & 5.22 & 6.04 & & 5.73 & & & 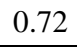 & 0.70 & 064 & & 0.72 & 0.71 \\
\hline & G. 20 & 780.5 & 7850.6 & 7945.4 & \begin{tabular}{|l|}
7858.8 \\
\end{tabular} & 7900.2 & 7990.4 & 8055.4 & 7982.0 & 5 & 6. & 5.74 & 5 & & & & 5.49 & & & 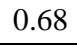 & 2 & 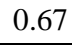 & & 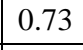 & 0.74 \\
\hline M & & 7707.8 & 7768.2 & 7900.6 & 7792.2 & 7867.8 & 7948.0 & 8010.8 & 7942.2 & 5.36 & 6.06 & 5.90 & 5.78 & 5.18 & 5.94 & 5 & 5.61 & 0.66 & 0.77 & 0.70 & 0.71 & 0.66 & 0.79 & 0.73 & 0.72 \\
\hline & G.T. 54-9 & 7970.4 & 8087.3 & 8327.2 & 8128.3 & 8136.9 & 8327.2 & 8497.4 & 8320.5 & 5.42 & 6.29 & 6. & 5.94 & 5.26 & 62 & 6 & 5.85 & 0.62 & 0.77 & 0.71 & 0.70 & 0.61 & 6 & 0.71 & 0.69 \\
\hline & G. 2003-47 & 70.5 & 8227.3 & 8443.9 & 8247.2 & 8210.4 & 8473.8 & 8600.3 & 8428.2 & 5.29 & 6.23 & 5. & 5.81 & 5 & 5 & 5.7 & 5.59 & 7 & 2 & 0.72 & 0.74 & 0.67 & 2 & 0.76 & 0.75 \\
\hline Mean o & ed rate & 8045.5 & 8192.3 & 8414.7 & & 8197.7 & 8427.9 & 8557.3 & & 5.34 & 6.23 & 5.98 & & 5.16 & 6.05 & $J .0$ & & 0.04 & 0.79 & 0.72 & & 0.64 & 0.79 & 0.74 & \\
\hline
\end{tabular}


by 0.68 and 0.78 than that recorded by planting it by 1.0 and 2.0 rows of cane setts, in the $1^{\text {st }}$ season as well as 0.65 and 0.52 , in the $2^{\text {nd }}$ one, respectively. Similarly the increases in sugar yield amounted to 1.33 and 0.48 ton/fed were gained, in the $1^{\text {st }}$ season, corresponding to 1.41 and 0.35 ton/fed, in the $2^{\text {nd }}$ one. The influence of plant density of sugarcane was reported by Shahid et al. (2002)and El-Geddawy et al. (2015).

The interaction of irrigation intervals with sugarcane varieties significantly affected sugar recovery\%, in both seasons and sugar yield, in the $2^{\text {nd }}$ one. The highest sugar recovery $\%$ was obtained from G. 2003-47 irrigated every 15 days. The highest sugar yield was produced from G. 2003-47 irrigated every 10 and/or 15 days, without significant variance in sugar yield as affected by these two irrigation intervals, in the $2^{\text {nd }}$ season (Table 4).

The interaction between irrigation intervals and seed rate had a significant influence on sugar recovery $\%$ in the $1^{\text {st }}$ season only, where the highest value of this trait was obtained by planting sugarcane using 1.5 rows of cane setts and irrigating it every 15 days. The same interaction significantly affected sugar yield ton/fed in both seasons. The highest sugar yield was attained by planting sugarcane with 1.5 drills of cane cutting and irrigating it 15-day intervals, in the $1^{\text {st }}$ season and/or 10-day intervals, in the $2^{\text {nd }}$ one.

Cane varieties $\mathrm{x}$ seed rate interaction had a significant effect on sugar recovery $\%$ and sugar yield in both season. Planting sugarcane G. 2003-47 at 1.5 rows of cane seeds gave the highest values of these two traits.

The second order interaction among the three studied factors had a significant effect on sugar recovery $\%$ and sugar yield/fed in both season. The highest values of these traits were mainly recorded by G. 2003-47 variety, planted with 1.5 rows of cane cuttings, when it was mostly irrigated at shorter intervals of 10 and/or 15 days (Table 4 ).

\subsection{Water consumptive use and water use efficiency}

Data in Table (5) point out that sugarcane water consumptive use increased by 316.3 and $751.3 \mathrm{~m}^{3}$ of water in the case of applying irrigation at 10 days compared with that irrigated at $15 \mathrm{and} /$ or 20 in the $1^{\text {st }}$ season, corresponding to 236.9 and $690.0 \mathrm{~m}^{3}$ water, in the $2^{\text {nd }}$ one, respectively. Data in Table 5 indicate that water use efficiency (WUE) calculated on cane-yield or sugar yield basis reached its maximum value when irrigation was given to sugarcane at 15 days intervals, followed by that applied at 10 days and 20 days.

Data in Table (5) show that G.2003-47 variety consumed 118.9 and $107.7 \mathrm{~m}^{3}$ of water higher than that consumed by G.T.54-9, in the $1^{\text {st }}$ and $2^{\text {nd }}$ season, respectively, which resulted in a reduction in the value of WUE calculated on cane yield basis. These results can be due to the higher number of millable canes/fed produced by G.2003-47 (Table 2), which may participated in raising the amount of water lost by transpiration from leaf stomata to the atmosphere. These results also could be attributed to lower cane yield/fed produced by the same variety compared to G.T.54-9 (Table 2). On the contrary, G. 2003-47 recorded higher value of WUE determined on sugar yield basis, which was probably referred to higher sugar yield/fed gained from this promising variety.

Raising seed rate from 1.0 to 1.5 and 2.0 rows increased the amount of water consumed by sugarcane plants by 369.2 and $222.4 \mathrm{~m}^{3}$ water, in the $1^{\text {st }}$ season, corresponds to 359.6 and $129.4 \mathrm{~m}^{3}$ water, in the $2^{\text {nd }}$ one, respectively. These results may be due to the gradual increase in the number of millable canes accompanied to increasing the number of buds in the used planting materials. On the contrary, seed rate of 1.5 rows recorded higher value of WUE determined on cane yield basis and sugar yield basis in both seasons.

\section{Conclusion}

Under the conditions of the present investigation, planting any of the evaluated cane varieties using 1.5 and/or 2.0 drills of cane setts and irrigating them at 10 and/or 15-day intervals can be recommended to get the maximum cane yield/fed. However, planting sugarcane variety G. 2003-47 using 1.5 drills of cane cuttings and irrigating it every 15 days cane be recommended to obtain the highest sugar yield/fed.

\section{REFERENCES}

Abd El-Aal A.M., El Shiekh S.R.E. and Fergany M.A. (2015). Ratooning ability of some sugarcane promising varieties under different levels of nitrogen fertilization. Egypt. J. Appl. Sci., 30 (1): 23-34.

Ahmed A.Z. (2003). Assessment of the optimum nitrogen level and seed rate for two promising sugarcane varieties. Egypt. J. Appl. Sci., 18 (6-B): 559-573.

Ahmed A. M., Nafi A. I. and Bekheet M. A. (2011). Yield and quality of some 
promising sugar cane varieties as affected by planting pattern. J. Plant prod., Mansoura Univ., 2(9): 12211232.

Ahmed Z.A., Ahmed A.M. and El-Soghier K.S. (2014). Evaluation of three sugarcane varieties grown under different number of irrigations. Egypt. J. Agric. Res., 92(2): 765-778.

Association of Official Agricultural Chemist (1995). Official methods of analysis puplished by the A.O.A.C., Box 540, Washington, D.C.,USA.

Avtar S. (2000). Influence of seed rate and row spacing on the growth and yield of late planted sugarcane. Sugar Tech., 2(3): 49-50

Bekheet M.A. (2006). Effect of irrigation and potassium fertilization on yield and quality of two sugarcane varieties. Assiut J. Agric. Sci., 37(1):1-20.

El-Geddawy I. H. Dalia; Makhlouf B.S. and Bekheet M.A. (2015). Performance of some sugarcane promising varieties under different seed sett rates and potassium fertilization. Int'l. J. of Curr. Microbiol. App. Sci., 4(11): 92-110

El-Geddawy I.H., El-Aref A.O., Ibrahim M.M. and Ali A.M.K. (2012). Performance of some sugarcane varieties under nitrogen fertilization of sugarcane Succharum officinarum L. to the plant levels and harvesting dates. Egypt. J. Appl. Sci., 27 (12): 520539.
El-Sogheir K. S. (1999). Levelling, planting and harvesting of sugarcane under traditional and mechanical methods. Ph. D. Thesis, Fac.

Agric., Minia Univ., Egypt.

Gomaa A.M.E.G. (2000). Physiological studies on the response of sugarcane to irrigation. Ph.D. Thesis, Agron. Dept., Fac. Agric. Al-Azhar, Univ., Egypt.

Hossain S.M.A., Eusufzai S.U.K. and Rahman M.A. (2009). Effect of different irrigation levels on growth and yield parameters of sugarcane. Pakistan J. Agric. Res., 22(1-2): 28-35.

Ismail A.M.A., Bekheet M.A. and Abo El-Hamd A.S. (2008). Yield and quality of four sugarcane varieties as influenced by seed rate and nitrogen fertilization. Egypt. J. Appl. Sci., 23 (1): 107-123.

Israelsen O.W. and Hansen V.E. (1962). Irrigation principles and practices. $3^{\text {rd }} \mathrm{Ed}$., John Villey and Sons Inc., New York.

Shahid B., Khan M. Z. and Naeem A. (2002). Yield and quality of sugarcane as influenced by inter row spacing and seed rate. Pak. Sugar J., 17(4): 7-9.

Snedecor G.W. and Cochran W.G. (1981). Statistical Methods. $7^{\text {th }}$ Ed. Iowa State Univ. Press, Ames, Iowa, USA.

Vites F.G. Jr. (1965). Increasing water use efficiency by soil management. Am. Soc. Agron., Madison, Wisc. Pp. 259-274.

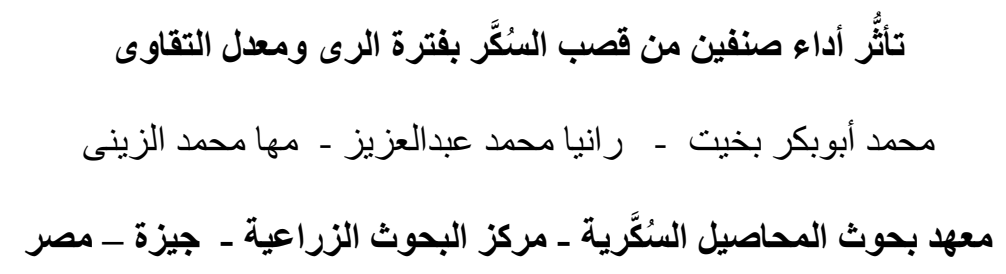

أقيمت تجربتان حقليتان فى محطة البحوث الزراعية بجزيرة شندويل (دائرة عرض 31.7651 ملخص 26.5013 شمالاً وخط الطول

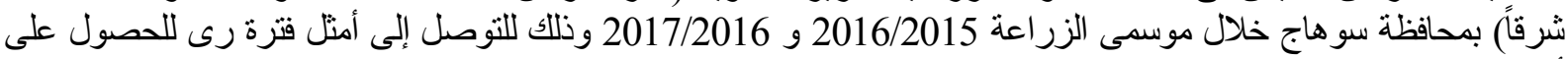

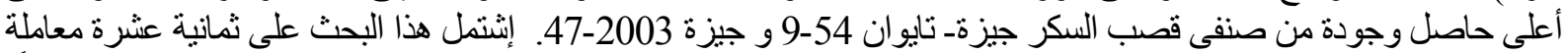

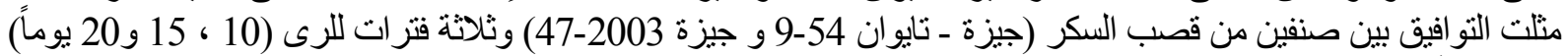

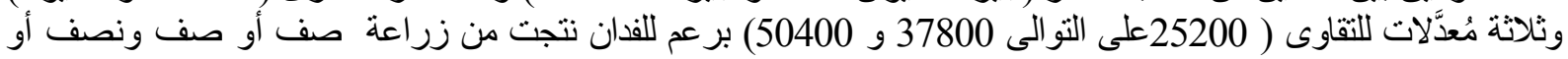

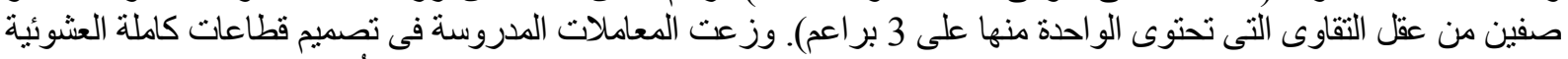

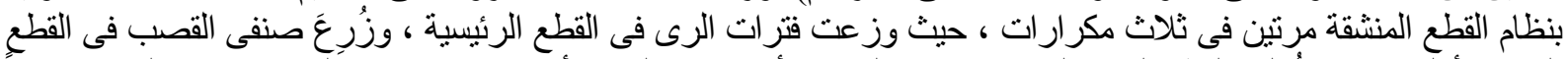

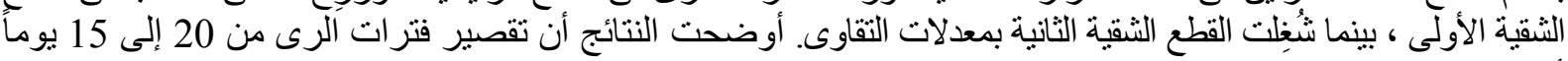

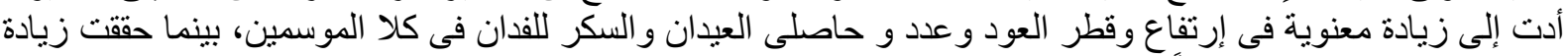
الفترة بين الريات إلى 20 يوماً زيادة إيجابية فى النسبة المئوية لكلٍ من البركس و السكروز واليكر وناتج السكر فى كلا الموسمين. 


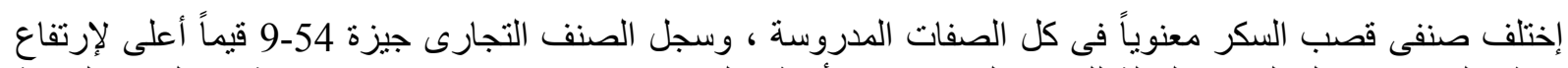

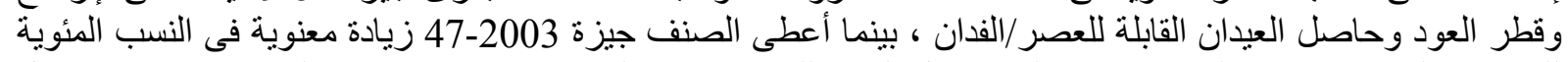

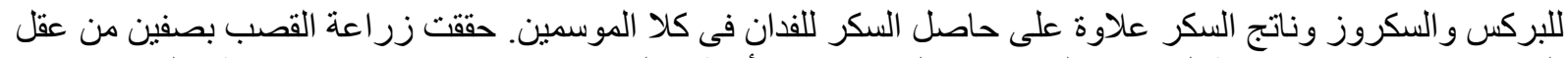

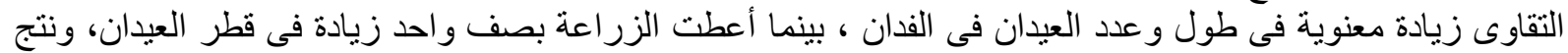

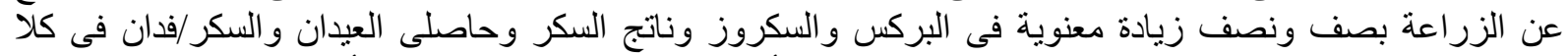

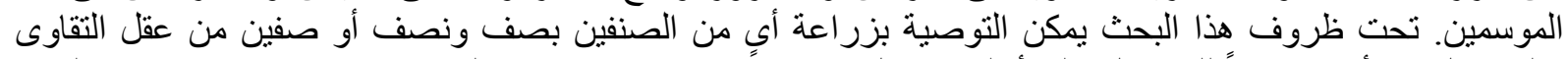

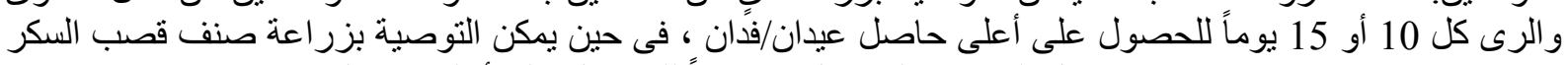

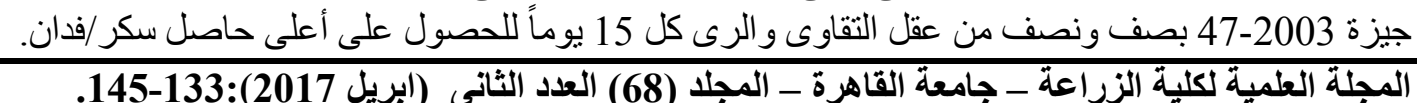

